\title{
Recipientes e substratos na produção de mudas e no cultivo hidropônico de tomilho (Thymus vulgaris L.)
}

DONEGÁ, M.A.;; FEREZINI, G.; MELLO, S.C.; MINAMI, K.; SILVA, S.R.

Universidade de São Paulo - Escola Superior de Agricultura "Luiz de Queiroz", Av. Pádua Dias, 11 CEP: 13418900. Piracicaba-SP, Brasil *donegamateus@gmail.com

\begin{abstract}
RESUMO: Bandejas com diferente número de células (128, 200 e 288) e dois substratos (fibra de casca de coco e casca de pinus) foram avaliados para a produção de mudas de tomilho e sobre o desempenho das plantas em sistema hidropônico. Para ambos os experimentos, o delineamento foi em blocos ao acaso. As mudas provenientes de estaquia foram avaliadas aos 30 dias quanto ao comprimento e massa seca de raízes. Aos 40 dias após o transplante das mudas, as plantas cultivadas em sistema hidropônico foram avaliadas quanto à massa fresca da parte aérea, massa seca da parte aérea e massa seca das raízes. A maior massa seca de raízes foi obtida para as mudas cultivadas em substrato à base de casca de fibra de coco. As mudas com maior comprimento de raízes foram obtidas nas bandejas com 128 e 200 células. As plantas de tomilho provenientes de mudas produzidas em bandejas de 128 células apresentaram maior massa fresca da parte aérea, massa seca da parte aérea e massa seca das raízes.
\end{abstract}

Palavras-chave: Thymus vulgaris, propagação, bandejas, estaquia, fibra de coco.

ABSTRACT: Containers and substrates on seedling production and hydroponic cultivation of thyme (Thymus vulgaris L.). Trays with different number of cells (128, 200 and 288) and two substrates (coir and pine bark-based) were studied for thyme seedling production and plant development in hydroponic system. In both experiments, experimental design was in randomized blocks. Seedlings from cuttings were evaluated at 30 days as to root length and dry matter. At 40 days after transplanting, plants grown in hydroponic system were evaluated for shoot fresh matter, shoot dry matter and root dry matter. The highest root dry matter was detected in seedlings grown in coir-based substrate. Seedlings that presented the greatest root length were obtained by using trays with 128 and 200 cells. Thyme plants from seedlings produced in trays with 128 cells had higher shoot fresh matter, shoot dry matter and root dry matter.

Keywords: Thymus vulgaris, propagation, trays, cutting, coir

\section{INTRODUÇÃO}

O tomilho pertence à família Lamiaceae e é nativo da região do Mediterrâneo. Apesar de ser classificado como hortaliça condimentar essa espécie vem sendo utilizada desde a antiguidade para fins medicinais. Suas folhas e flores são as partes utilizadas para o consumo como condimento e para extração de óleo essencial. Os principais constituintes do óleo essencial do tomilho são o timol, terpineno, cinemo, carvacol e linanol, os flavonóides, o ácido cafeico e o ácido labiático, derivados de diferentes partes da planta (Porte \& Godoy, 2008; Sharafzadeh et al. 2010).

O tomilho pode ser multiplicado por sementes, divisão de touceiras e estacas.
As sementes de tomilho apresentam grande variabilidade e diversidade genética devido a sua elevada taxa de cruzamento, que causa alterações físico-químicas dos componentes aromáticos e do óleo essencial (Mewes et al. 2008). Com o propósito de manter a qualidade dos compostos aromáticos e medicinais, a propagação por estacas apicais é o método mais adequado (Minami et al. 2010; Shabnum \& Wagay, 2011).

Os principais recipientes utilizados para a produção de mudas de hortaliças e plantas medicinais são as bandejas de poliestireno e de polietileno com 128, 200 ou 288 células, que podem variar de 50 até 400 células dependendo da 
necessidade do agricultor. A absorção de nutrientes, água, e a produção, são afetadas pela restrição das raízes e, portanto, o volume de substrato, que é determinado pelo tamanho do recipiente é um fator importante para o crescimento das mudas e consequentemente, para o desenvolvimento da planta nos diferentes sistemas de cultivo (Nesmith \& Duval, 1998).

Os substratos comerciais são compostos principalmente por casca de pinus, vermiculita, turfas, carvão moído, casca de arroz carbonizada, e fibra de casca de coco. A escolha do substrato deve estar pautada nas necessidades da planta que se deseja cultivar, no sistema de cultivo, nas características físico-químicas do substrato, bem como na sua disponibilidade.

\section{OBJETIVO}

O objetivo deste trabalho foi avaliar bandejas de poliestireno expandido com diferente número de células e tipos de substratos no desenvolvimento de mudas de tomilho e na produção das plantas de tomilho em sistema hidropônico.

\section{MATERIAL E MÉTODO}

O experimento foi realizado na área experimental do Departamento de Produção Vegetal da Escola Superior de Agricultura "Luiz de Queiroz" em duas etapas: produção de mudas e cultivo em sistema hidropônico.

Estacas apicais de cinco centímetros de comprimento foram coletadas de plantas matrizes de tomilho localizadas na área experimental do Departamento de Produção Vegetal ESALQ/USP. $O$ delineamento utilizado foi o de blocos ao acaso, em esquema fatorial $(3 \times 2)$ três números de células em bandejas de poliestireno expandido $(128,200$ e 288) e dois substratos, um à base de fibra de casca de coco (Goldem Mix tipo $12 \mathrm{com}$ pH 6,0 e condutividade elétrica de $0,6 \mathrm{dS} \mathrm{cm}^{-1}$ ) e outro à base de casca de pinus (Basaplant Hortaliça BX com pH 5,8 e condutividade elétrica de $2,5 \mathrm{dS} \mathrm{cm}^{-1}$ ) com três repetições, sendo cada unidade experimental constituída de 80 células da bandeja de poliestireno expandido com uma estaca em cada. As bandejas foram mantidas em estufa agrícola por 30 dias, quando as mudas foram avaliadas quanto à massa seca de raízes (MSR) e comprimento médio das raízes (CPR). Os dados foram submetidos à análise de variância e as médias foram comparadas pelo teste Tukey a $5 \%$ de probabilidade.

As mudas remanescentes de cada tratamento do ensaio anterior foram transplantadas para o sistema hidropônico, aos 30 dias após a estaquia. $O$ delineamento utilizado foi o mesmo adotado para a produção de mudas, sendo que nesse caso, cada unidade experimental foi constituída de 20 plantas dispostas nos perfis do sistema hidropônico. O sistema hidropônico utilizado foi o NFT (fluxo laminar de nutrientes). Cada bloco foi composto por quatro perfis de polipropileno com 6 metros de comprimento, espaçados 100 $\mathrm{mm}$ entre si e dispostos em declividade de $4 \%$ com $75 \mathrm{~mm}$ de largura, $45 \mathrm{~mm}$ de profundidade e orifícios espaçados de $150 \mathrm{~mm}$. As bancadas foram alimentadas individualmente por reservatórios de 250 litros. A circulação da solução nutritiva foi efetuada por um temporizador eletrônico programado para permanecer 15 minutos ligado e 15 minutos desligado, entre 05:30 e 18:30 horas e por 15 minutos ligado as 20:30, 00:30 e 04:30 horas. A solução nutritiva utilizada apresentava a seguinte composição, em mgL-1: 800 nitrato de cálcio; 400 nitrato de potássio; 100 sulfato de potássio; 140 fosfato monopotássico; 35 fosfato monoamonico; 250 nitrato de magnésio e 150 sulfato de magnésio. Os micronutrientes foram fornecidos por um fertilizante, composto por $0,5,2,5,0,5,0,1,0,5$ e 0,5 $\mathrm{mg} \mathrm{L}^{-1}$, respectivamente, de B, Fe, Cu, Mo, Mn e Zn. Nas duas primeiras semanas de cultivo a solução

TABELA 1. Análise de variância para as variáveis massa seca de raízes (MSR), comprimento de raízes (CPR) para mudas e massa fresca aérea (MFA), massa seca aérea (MSA) e massa seca de raízes (MSR) de plantas de tomilho no momento da colheita. Piracicaba-SP, USP/ESALQ, 2010.

\begin{tabular}{llllll}
\hline & \multicolumn{3}{l}{$\begin{array}{l}\text { Colheita } \\
\text { Produção de Mudas } \\
\text { Falor de F }\end{array}$} & \multicolumn{2}{l}{ Valor de F } \\
Fontes de Variação & MSR & CPR & MFA & MSA & MSR \\
\hline Bloco & $0,79^{\text {ns }}$ & $0,78^{\text {ns }}$ & $0,06^{\text {ns }}$ & $0,18^{\text {ns }}$ & $0,42^{\text {ns }}$ \\
Bandeja (B) & $0,49^{\text {ns }}$ & $7,71^{* *}$ & $12,39^{* *}$ & $11,76^{* *}$ & $20,62^{* *}$ \\
Substrato (S) & $4,09^{*}$ & $1,39^{\text {ns }}$ & $0,02^{\text {ns }}$ & $0,23^{\text {ns }}$ & $0,01^{\text {ns }}$ \\
BxS & $1,35^{\text {ns }}$ & $2,86^{\text {ns }}$ & $0,72^{\text {ns }}$ & $0,50^{\text {ns }}$ & $2,49^{\text {ns }}$ \\
\hline CV \% & 3,11 & 28,00 & 16,84 & 13,37 & 4,63 \\
\hline
\end{tabular}

ns, ***: não significativo e significativo a 5 e $1 \%$, respectivamente. 
foi utilizada a $50 \%$ de concentração.

A colheita foi realizada 40 dias após o transplante das mudas, quando foram avaliadas: massa fresca da parte aérea (MFA) massa seca da parte aérea (MSA) e massa seca das raízes (MSR). Os dados foram submetidos à análise de variância e as médias foram comparadas entre si pelo teste Tukey a $5 \%$ de probabilidade.

\section{RESULTADOS E DISCUSSÃO}

Não houve interação significativa entre o número de células e o tipo de substrato para o comprimento e massa seca de raízes de mudas de tomilho. Entretanto, houve efeito significativo do tipo de substrato para massa seca de raízes e do número de células para o comprimento de raízes (Tabela 1).

A massa seca de raízes foi afetada pelo tipo de substrato, com incremento de $55 \%$ dessa característica para as mudas produzidas em substrato à base de fibra de casca de coco (Tabela 2). Esse resultado corrobora com Zietenamm \& Roberto (2007) que obtiveram maior massa seca de raízes quando utilizaram substrato à base de casca de coco. A aeração é uma das características físicas mais importantes para o crescimento de mudas em recipientes, pois, garante a retenção de água suficiente para o desenvolvimento da muda e o espaço poroso necessário para o fornecimento de oxigênio (Minami, 2010). Segundo Carrijo et al. (2002) a aeração adequada da fibra de casca de coco é o principal fator responsável pela qualidade superior desse substrato. Parte dessa qualidade pode ser atribuida a porosidade interna das particulas do material que constiutui o substrato (Barreto et al. 2012).

As mudas produzidas em bandejas de 128 e 200 células não diferiram entre si, porém, apresentaram comprimento de raízes superior às produzidas em 288 células (Tabela 3 ). Resultados semelhantes foram obtidos para mudas de alface e de couve-flor (Marques et al. 2003; Godoy \& Cardoso, 2005). A produção de mudas em recipientes de maior
TABELA 2. Massa seca de raízes (MSR) de mudas de tomilho em função do substrato. Piracicaba-SP, USP/ESALQ, 2010.

\begin{tabular}{lll}
\hline Substrato & \multicolumn{2}{c}{$\begin{array}{l}\text { MSR } \\
(\mathrm{mg})\end{array}$} \\
\hline Fibra de coco & 31,3 & $\mathrm{a}^{*}$ \\
Casca de Pinus & 14,2 & $\mathrm{~b}$ \\
\hline
\end{tabular}

"Medias seguidas da mesma letra não diferem entre si pelo teste Tukey a $5 \%$ de probabilidade.

TABELA 3. Comprimento de raízes (CPR) de mudas de tomilho em função do número de células por bandeja. Piracicaba-SP, USP/ESALQ, 2010.

\begin{tabular}{lll}
\hline Bandeja & \multicolumn{2}{c}{ CPR } \\
$(\mathrm{cm})$ & \\
\hline 128 & 4,73 & $\mathrm{a}^{*}$ \\
200 & 4,64 & $\mathrm{a}$ \\
288 & 3,47 & b \\
\hline
\end{tabular}

"Médias seguidas da mesma letra não diferem entre si pelo teste Tukey a $5 \%$ de probabilidade.

volume não apresentam restrição ao crescimento radicular, otimizando, o fornecimento de nutrientes, água, luz e, consequentemente, o crescimento das plantas (Pereira \& Martinez, 1999).

Não houve interação significativa entre o número de células por bandeja e o tipo de substrato para massa fresca da parte aérea, massa seca da parte aérea e massa seca de raízes em plantas de tomilho cultivadas em sistema hidropônico (Tabela 1).

A massa fresca da parte aérea, a massa seca da parte aérea e das raízes foram superiores para as plantas provenientes de mudas produzidas em bandejas de 128 células (Tabela 4).

Maiores produções de alface, beterraba e pepino foram encontradas quando as mudas foram

TABELA 4. Massa fresca aérea (MFA), massa seca aérea (MSA) e massa seca de raízes (MSR) de plantas de tominho cultivadas em sistema hidropônico em função do número de célula por bandeja. Piracicaba-SP, USP/ ESALQ, 2010.

\begin{tabular}{|c|c|c|c|c|c|c|}
\hline \multirow{2}{*}{ Bandeja } & \multirow[t]{2}{*}{ MFA } & & \multicolumn{2}{|l|}{ MSA } & \multicolumn{2}{|l|}{ MSR } \\
\hline & & & $\ldots \ldots \ldots$ & ... & $\ldots \ldots$. & \\
\hline 128 & 4,78 & $a^{*}$ & 1,39 & $a$ & 0,21 & $a$ \\
\hline 200 & 3,45 & $\mathrm{~b}$ & 1,01 & b & 0,13 & $b$ \\
\hline 288 & 2,78 & b & 0,78 & b & 0,11 & $b$ \\
\hline
\end{tabular}

"Medias seguidas da mesma letra não diferem entre si pelo teste Tukey a $5 \%$ de probabilidade. 
produzidas em recipientes com maior volume de célula (Leal et al. 2011; Costa et al. 2012). Godoy \& Cardoso (2005) observaram maior número de folhas e produção total de couve flor proveniente do transplante de mudas produzidas em bandejas de 128 células. Os autores atribuíram esse resultado à maior qualidade da muda, o que refletiu no crescimento das plantas. Reghin et al. (2006) também obtiveram maior produtividade, massa fresca e massa seca de plantas de chicória oriundas de bandejas com 128 células.

\section{CONCLUSÃO}

Plantas de tomilho cultivadas em sistema hidropônico apresentaram maior desenvolvimento quando oriundas de mudas produzidas em bandejas de 128 células.

\section{REFERÊNCIA}

BARRETO, C.V.G.; TESTEZLAF, R.; SALVADOR, C.A. Dinâmica do potencial matricial em substratos de pinus e coco sob ação da capilaridade. Horticultura Brasileira, v. 30, p. 26-31, 2012.

CARRIJO, O. A. et al. Fibra de coco verde como substrato agrícola. Horticultura Brasileira, v. 20, p. 533-535, 2002.

COSTA, E.; VIEIRA, L.C.R.; LEAL, P.A.M.; JARA, M.C.S.; SILVA, P.N.L. Substrate with organosuper for cucumber seedlings formation in protected environment and polystyrene trays. Revista de Engenharia Agrícola, v.32, p.226-235, 2012.

GODOY, M.C.; CARDOSO, A.I. Produtividade da couve-flor em função da idade de transplantio das mudas produzidas e tamanhos de células na bandeja. Horticultura Brasileira, v.23, p.837-840, 2005.

LEAL, P.A.M.; COSTA, E.; SHIAVO, J.A.; PEGORARE, A.B.; Seedling formation and field production of beetroot and lettuce in Aquidauana, Mato Grosso do Sul, Brazil. Horticultura Brasileira, v. 29, p. 465-471, 2011.

MARQUES, P.A.A. et al. Qualidade de mudas de alface formadas em bandejas de isopor com diferentes números de células. Horticultura Brasileira, v. 21, n. 4, p. 649-651, 2003.

MEWES, S.; KRUGER, H.; PANK.; F. Physiological, morphological, chemical and genomic diversities of different origins of thyme (Thymus vulgaris L.). Genetic Resource and Crop Evolution, v. 88, p. 1303-1311, 2008.

MINAMI, K. et al.; Tomilho: uma importante planta aromática. Piracicaba:ESALQ - Divisão de Biblioteca e Documentação, 2010. 31p. (Série Produtor Rural, n47).

MINAMI, K. Produção de mudas de alta qualidade. Piracicaba, 2010. 440 p.

NESMITH, D.S., DUVAL, J.R. The effect of container size. HortTechnology, v.8, n.4, p.495-498, 1998.

PEREIRA, P. R. G.; MARTINEZ, H. E. P. Produção de mudas para o cultivo de hortaliças em solo e hidroponia. Informe Agropecuário, Belo Horizonte, v. 20, p.24-31, 1999.

PORTE, A.; GODOY, R. Chemical composition of Thymus vulgaris L. essential oil from Rio de Janeiro State (Brazil). Journal of Serbian Chemical Society, v. 73, p. 307-310, 2008.

REGHIN, M.Y. et al. Efeitos do tipo de bandejas e de cultivares na produção de plântulas e no rendimento da chicória. Ciência e Agrotecnologia, v. 30, p. 435443, 2006.

SHABNUM, S.; WAGAY, M. Micropropagation of different species of Thymus. Journal of Research \& Development, v.11, p.71-80, 2011

SHARAFZADEH, S.; KHOSH-KHUI, M.; JAVIDNIA, K.; ALIZADEH, O.; ORDOOKHANI, K. Identification and comparison of essential oil components in leaf and stem of gardem Thyme grown under greenhouse conditions. Advances in Environmental Biology, v. 4, p. 520-523, 2010.

ZIETEMANN, C.; ROBERTO, S. R. Produção de mudas de goiabeira (Psidium guajava L.) em diferentes substratos. Revista Brasileira de Fruticultura, v.29, p. 137-142, 2007. 